\title{
CROSS-BORDER MOBILITY AND STRATEGIES OF DEVELOPMENT AMONG RETURNED MOLDAVIAN IMMIGRANTS
}

\author{
Silvia Marcu \\ Consejo Superior de Investigaciones Científicas (CSIC) \\ C/Albasanz 26-28; 28037 Madrid (Spain) \\ Silvia.marcu@,cchs.csic.es
}

0034916022311

\section{Silvia Marcu, Ph.D. Postdoctoral Researcher “Ramón y Cajal” (RYC 2009-03834).}

Silvia Marcu works and lives in Spain. For the last decade conducting research into international migration, identity and mobility: Frontiers and flows of immigration from Eastern Europe to Spain; Studies of Geopolitics: Eastern Europe, Russia, European Union (EU) and International Relations.

This article comes as a result of the research project entitled: "Eastern European Migration to Spain in the context of border geopolitics: circulatory mobility and return," (CSO 2010-14870), with funding from the Spanish Ministry of Science and Innovation and coordination by the author. 


\begin{abstract}
Borders and human mobility have become key elements in the development of the global society of the $21^{\text {st }}$ century. Growing attention to the development potential of migration has recently raised a new concern regarding the issue of return migration. Linked to this, the debate on the migration-development nexus considers circulation to foster development as it enhances the flow of financial, social and cultural capital to the countries of origin. This article links cross-border mobility and return to development migration. Taking into account the historical, geopolitical and social changes in Moldova, the paper examines the perceptions of mobility and return for development of the Moldovans engaged in emigration in the countries of the European Union (EU). Using a multi-discipline approach and ethnographic research (in-depth interviews) conducted among Moldovan migrants in their home country, this article seeks to analyze how mobility and return can support social change and development within the country.
\end{abstract}

Keyword: cross-border mobility, development, return, Moldova, reintegration

\title{
1. Introduction
}

Over the last two decades, there have been profound transformations in the territory and society of Eastern Europe characterized by fundamental factors interacting with each other: migration/mobility, return and development. One of the countries sensitive to this global issue is Moldova, which was created in 1991 following the collapse of the Soviet Union. Moldova is, thus, a multi-ethnic country divided by a still-unresolved secessionist conflict (1991-1992) as well as conflicting interpretations as to national and ethnic identity (Marcu, 2009; King, 2003).

With regard the mobility process, the return of immigrants became ever more obvious, while the ease with which Moldovans can obtain Romanian citizenship expanded the process of crossborder mobility into Europe, especially following Romania's entry into the EU. Return does contribute to national development since Moldova is a country that practically survives thanks to emigration: $38 \%$ of GNP is derived from emigrants' remittances (IOM, 2011). 1

This article aims to highlight the influence of mobility and return on the development of Moldovans who emigrate to EU countries. At the same time, it investigates their re-integration 
processes and the development impact on Moldova. First, the paper examines how the geopolitical position on the EU border and the possibility of citizens of Moldova getting Romanian citizenship influence the increase in cross-border mobility with the EU. Secondly, we ask what role return plays in the development of Moldova. As Pinger (2009) notes, only if migrants return can the sending country benefit from the skills and experience acquired abroad. Thirdly, we try to find out how the return of Moldovans and the opening of businesses across the Dniester facilitate the coexistence between people and the easing of tensions. Finally, the paper examines the impact of immigrant returnees in Moldova on re-integration.

After a presentation of the theoretical and methodological background of the study, the empirical analysis presents the narratives of returned Moldovan immigrants, taking into account crossborder experiences, return and development strategies, working in Transnistria, and the impact on re-integration in Moldova. The paper ends with some reflections on how mobility, return, and reintegration can support social change and development within the country.

\section{Cross-border mobility and return for development}

Following the advance of EU borders towards Eastern Europe, there was a fundamental change in the nature of border; the transnationalism of the migrants as a result of the intense process of mobility (Agnew, 2008; Gielis, 2009; Newmann, 2006). There are two perspectives on borders that have come to dominate the discussions surrounding European borders in recent times: securitized borders associated with the process of 'rebordering' (Andreas, 2003), and borderless Europe (the single market and its associated mobilities). While rebordering highlights the increasing securitization and impermeability of borders associated with the 'Schengenland' model of enhanced mobility within a common space protected by 'hard' external borders, the 
idea of 'undivided Europe' posits an extended communicative and economic space represented by the notion of 'network Europe'. As a result of the new choreography of border opening and ground-breaking trans-world, transnationalism has emerged as a cross-border field in which migrants on the move for work opportunities are continuously between here and there (Glick Schiller et al., 1992; Vertovec, 1999; Portes et al., 1999) and play an active role in shaping transnational space. Mobility and fluidity (Faist, 2000; Hannam et al., 2006) allow the building of networks across EU borders (Rumford, 2007). The new patterns of mobility from the East towards the countries of the West consist of temporary movement, incorporation into the undocumented labour market (Favell 2008), transnationalism (Vertovec, 1999), and the creation of transnational networks that include return for development.

The discourse on the links between migration and development is long-standing and as Hugo (2012, p.28) points out, it has swung between optimism about its potential benefits and pessimism. That said, it needs to be stressed that migration is no substitute for sound development policy and governance. As Ebeke (2012) argues, governments and international agencies are attracted to the idea of managing international migration -and its accompaniments, such as remittances and transnational ties- as a means of promoting development. This phenomenon may not be unique to mobility, but transnationalism has become a new way of conceptualizing migration. In this context, the notion of return appears in relation to current debates on transnational migration and migration-development linkages. King (2000) identifies a typology of return that is inclusive not only of permanent, but also occasional, seasonal and temporary returnees. Return, in other words, should not be intended as a "closure of the migration cycle, but rather as "one of the multiple steps of a continued movement" (Ammasari \& Black, 2001, p.12), so that the notion is able to incorporate a whole range of people with differing 
mobility patterns. In their influential book, Papademetriou \& Martin (1991) indicate return (together with recruitment and remittances) as one of the 3Rs: one of the key factors affecting development in the home country. The beneficial effects of remmitances have been amply debated, particularly since the World Bank (2003) first stated that they largely exceed in value the amount of foreign aid. Observers have underlined that at the macro-level, remmitances rarely boost long-term economic growth and might generate inflation; however, at the micro-level, they contribute to combating the poverty of individuals and housesholds (De Haan, 1999, Ammassari \& Black, 2001). In turn, Newland \& Patrick (2004) argue that research on migration and development needed to move "beyond remittances", and like them, we look to remittance behaviour. In her work, Levitt (2001) coined the term "social remittances" to call attention to the fact that, in addition to money, migrants export ideas and behaviours back to their sending communities. Levitt \& Lamba-Nieves (2011) observed four types of social remittance: norms, practices, identities and social capital. As Khagram \& Levitt (2001) note, understanding social remittance mobility requires a transnational optic.

The early literature on remittances suggests that migrants remit more if they plan to return to the home country (Galor \& Stark, 1990; Merkle \& Zimmermann, 1992). This is intuitive, because returnees, at least partly, benefit from their remittances after return, such that remittances can be considered as a special form of savings. Thus, the return can reactivate patterns of human mobility and development (Cassarino, 2004). King \& Christou (2011, p.454) note, that within return migration, there is a tension between mobility on the one hand, and a search for a stable homeland in which to settle and belong on the other. Thanks to return it is possible to question the binary vision of cross-border mobility, taking into account the movements which facilitate migrants' mobility (Chapman \& Prothero, 1983). 
Return migration and reintegration is another issue of increasing concern to researchers. Preston (1993, p.2-4) has argued that within migratory cycles, the process of integration is one of adaptation; a process of give and take on either side as people learn to live together. At places of origin, this adaptation takes place between those who have returned and those who remained at home during their absence. Arowollo (2000) proposes a programme approach for return migrants, and argues that governments should focus on the institutional mechanisms of programme management, including the creation of a responsible agency. As Athukorala (1986) points out, intervention strategies may include pre-return or on-arrival orientation to prepare for changes and difficulties to be encountered, provision of financial and investment advice for those hoping to start up a business or acquire property, provision of information about qualification and skill recognition for labour market entry.

\section{Moldova: Mobility towards EU}

To understand the mobility of Moldovans in EU countries, it is essential to explain some peculiarities of this country. On the Eastern European border (Fig.1) we are presented with a peculiar and sensitive situation. There are two states (Romania and Moldova) and one identity - a historical/cultural territorial unit profoundly marked by political segmentation (Marcu, 2011). The history of Moldova is one of constant change and contestation of territory, identities and loyalties. In the last two decades, there has been a search for the meaning of Moldovan identity which has led to political conflict. The 1992 civil war and the de facto state status of Transnistria demonstrate the difficulty that Moldovans have had in coming to terms with their identity. 


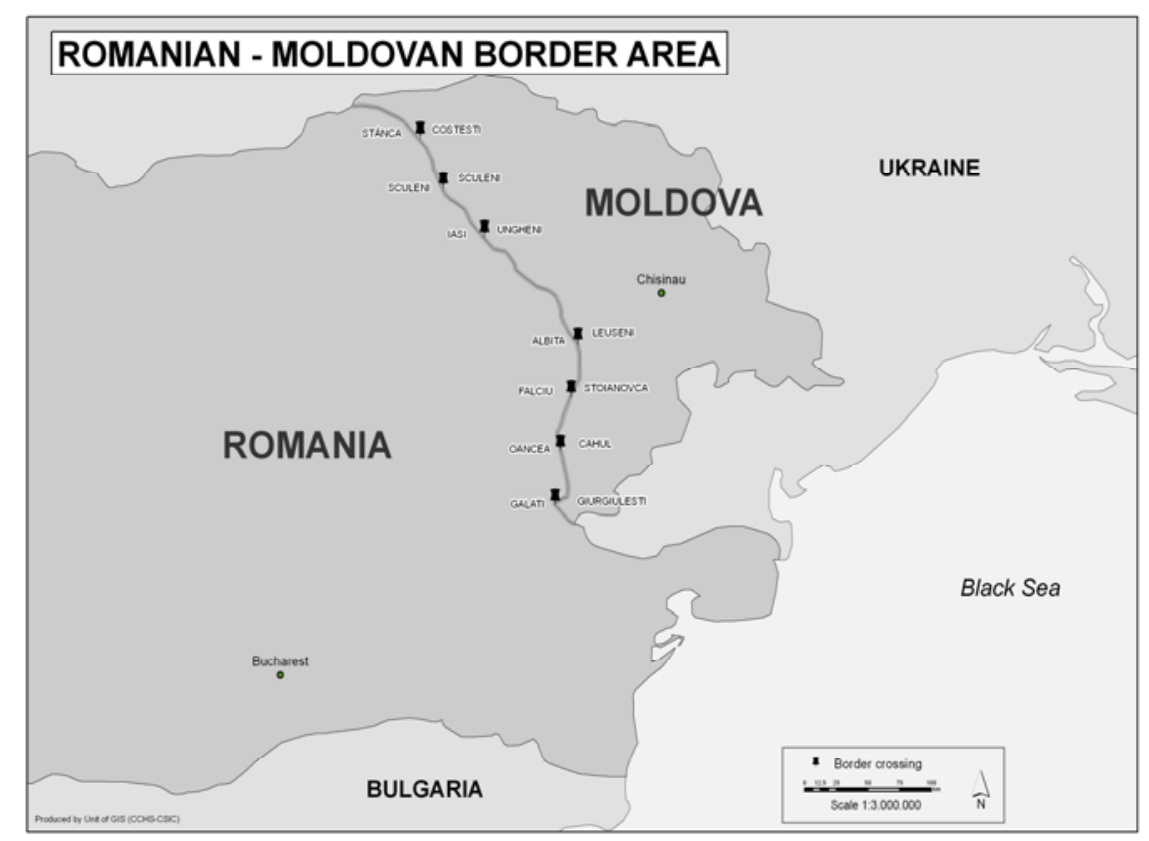

Fig.1. Romanian-Moldovan border area.

Source: Author's own elaboration.

The component population of Moldova by ethnic origin measured in the 2004 Population Census (Fig. 2) underscores the fact that Moldovans constitute $75.8 \%$ of the total population, an increase of $5.9 \%$ over 1989 .

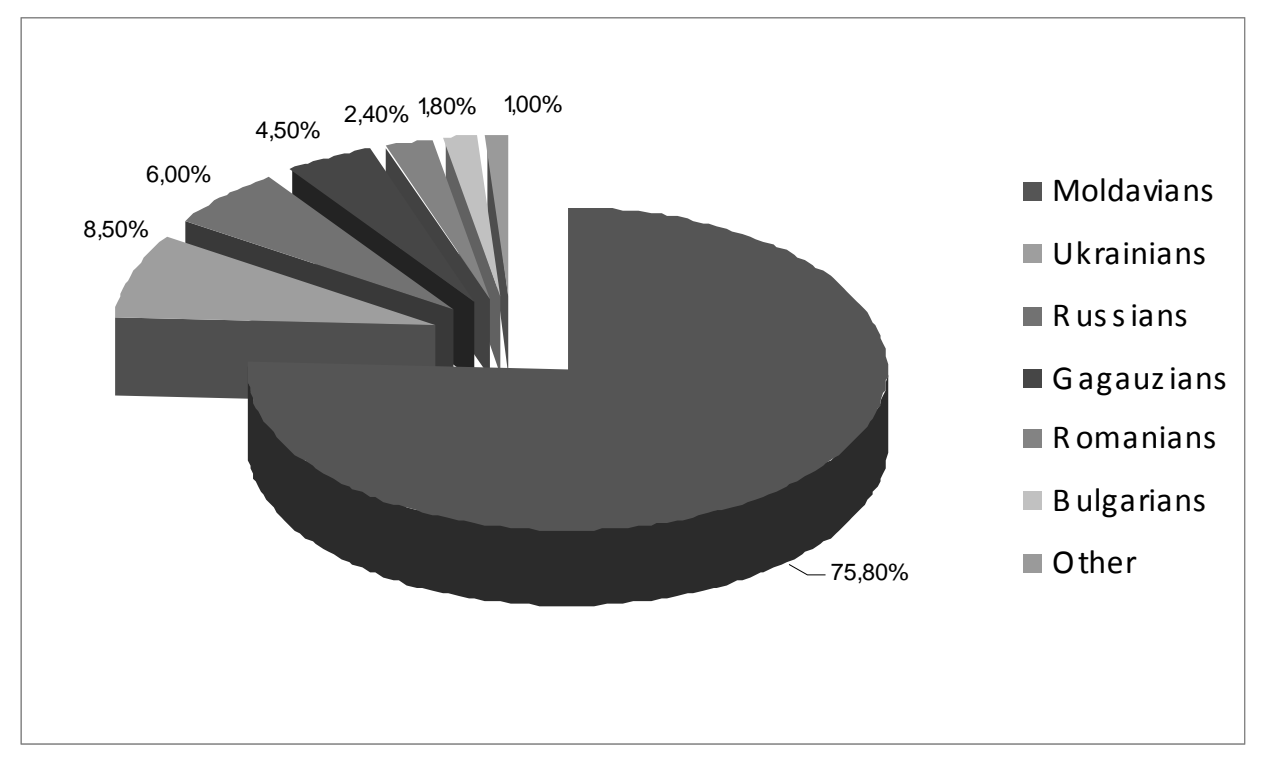


Fig. 2. Moldova: Population Structure

Source: Census of Population, 2004 Moldova

http://www.statistica.md/newsview.php?1=ro\&idc=168\&id=2358

In Transnistria, the largest single population group is Moldovan (31.9\%), but the Slavic minority groups of Ukrainians and Russians together represent the majority of the population (Figure 3).

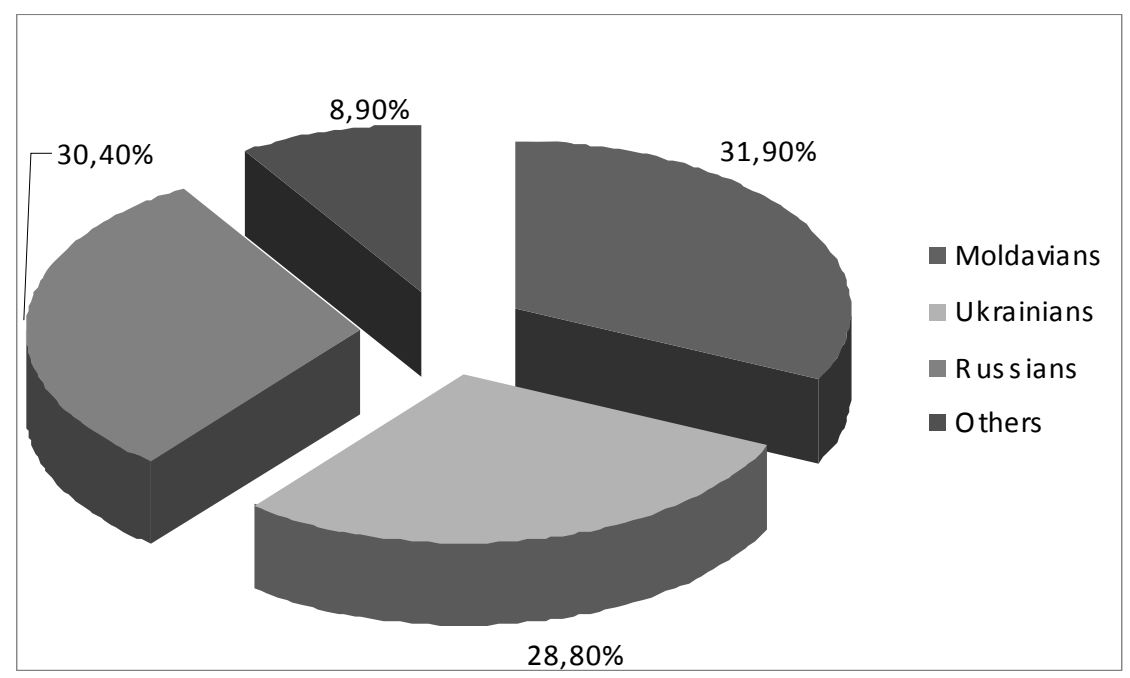

Fig. 3. Transnistria: Population Structure.

Source: Census of Population, 2004 Transnistria.

Since 1990 Moldova has experienced a number of economic shocks. First it lost control of its main energy and industrial plants because of a territorial conflict with the separatist province of Transnistria. This conflict caused significant disruption to the monetary and financial structure of the economy as well as to its education and health care systems. Second, an indirect, though significant, impact on the Moldovan economy resulted from the 1998 Russian economic crisis: the country's industrial output fell by $25 \%$, agricultural output by $20 \%$ and exports decreased by almost half in 1998-99. Partly as a result of the sharp decline in GDP in 1999, unemployment increased considerably -from 57,800 in 1999 to 62,300 in 2003 - resulting in high poverty rates 
in an already beleaguered economy (IOM, 2004). Even for some of the employed, wages are not high enough to meet the needs of a nuclear family. In the backdrop to this, the main avenue open to the unemployed or those on very low wages is to look for employment abroad.

\section{Moldovans in the EU}

Moldova has become a country of mass emigration since the mid-1990s. According to official government estimates, more than one quarter of the Moldovan labour force is currently living and working abroad with the actual figure differing according to sources and likely topping $600,000 . \underline{2}$ As a result, migrants are a major source of income for the development of the national economy, with an estimated 1.9 billion in remittances from those abroad in 2008 accounting for $38 \%$ of Moldova's GDP: the second-highest rate globally after Tajikistan. The country's real GDP per capita is the lowest in Europe and Moldova is classified as a low-income country by the World Bank. $\underline{3}$ Information on remittance patterns of Moldovan migrants is contained in the reports by Ruggiero (2005); Görlich \& Trebesch (2008). These authors find that the amount of remittances is generally positively correlated with the age of the migrant and negatively with the year of first departure, indicating that the amount remitted decreases with the length of stay.

The Moldovan migrant population can be divided into two broad groups. The first is the rural migrant majority, who have large families and tend to migrate to Russia or other Commonwealth of Independent States (CIS) countries, where migration costs are low and seasonal work in construction abound. The second group predominantly originates from wealthier and bettereducated urban households, and stays longer as the costs of migrating to these destinations are much higher (Cuc, Lundback \& Ruggieri 2005). The EU countries receiving the greatest numbers of Moldovans are Italy, Romania, Germany, Spain and the United Kingdom (Fig.4), where, in 
addition, immigrant networks promoting circulation and cross-border mobility have been set up (Rusnac et al., 2011; Culic, 2008).

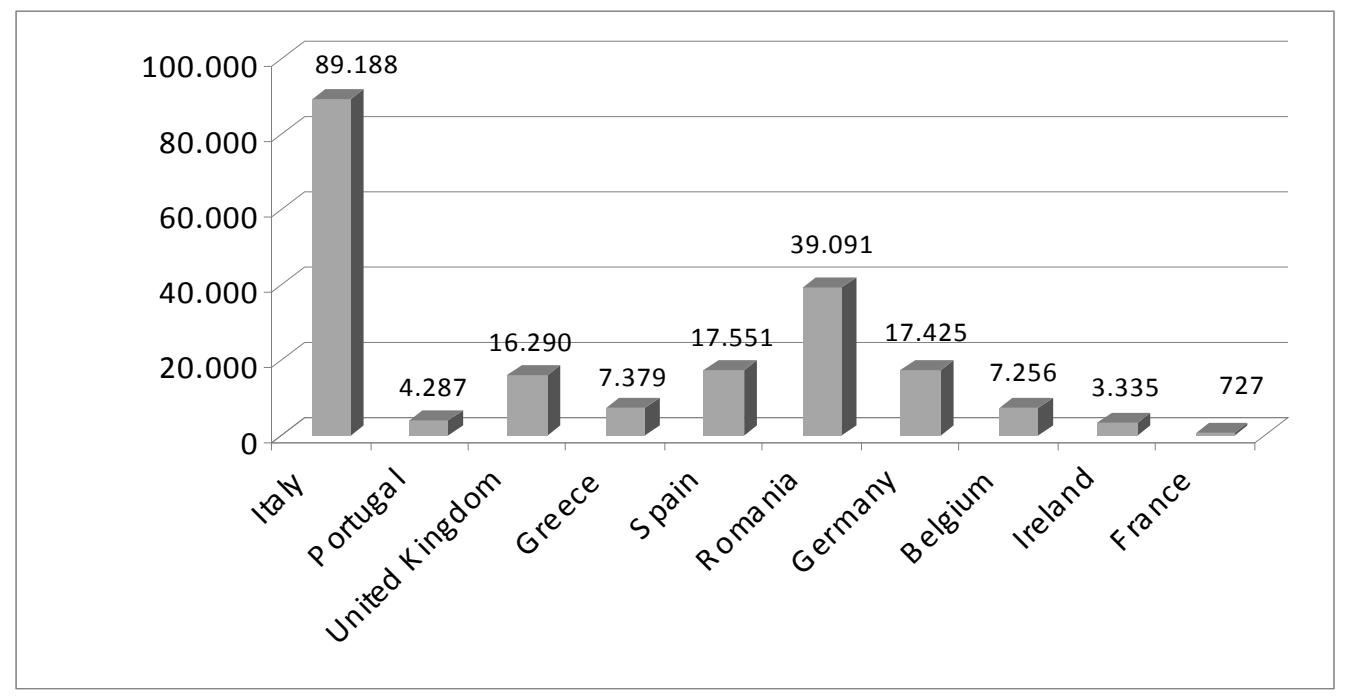

Fig. 4. Moldovan immigrants UE

Sources: Ratha and Shaw (2007) updated with additional data for 71 destination countries as described in the Migration and Remittances Factbook 2011.

http://econ.worldbank.org/WBSITE/EXTERNAL/EXTDEC/EXTDECPROSPECTS/0,,contentMDK:22803131 pag ePK:64165401 piPK:64165026 theSitePK:476883,00.html

The process of family reunification is also of great relevance. The rate of women emigrating is ever greater. According to statistics compiled by the Moldovan Border Service $\underline{4}$, an increasing number of pre-school children crossed over the border in 2012. In Italy, 89,188 Moldovans became legal residents, while in Spain the figure was 17,551. Of these, 13,000 in Italy had dual Moldovan/Romanian citizenship, while in Spain this amounted to 6,123. This demonstrates the growing number of Moldovans resorting to Romanian citizenship in order to circulate freely within the EU. The aim for the EU and the Republic of Moldova is to continue and intensify discussion and cooperation on the three main sections of the general approach to migration in these nations, namely, to better manage legal migration, to fight against irregular migration and to strengthen the relationship between migration and development. 


\section{Methodology and characteristics of the sample}

Our framework was developed from qualitative fieldwork with emigrant returnees to Moldova. $\underline{5} \mathrm{I}$ held 54 in-depth semi-structured interviews with a duration of between one and two hours. I interviewed 24 men and 20 women of working age who had returned from EU countries. All of them had a secondary or higher education. The interviewees had emigrated over the last 10 years to Italy (12), Spain (10), the United Kingdom (9), Ireland (3), Portugal (5), and Greece (5), having returned over the last year, even while some continue to engage in cross-border mobility. Besides Chisinau, the interviews were conducted in the cities of Anenii Noi and the town of Varnita, located on the border with Bender, Transnistria (the town was selected because the inhabitants are near enough to Transnistria for it to feature in their daily lives), Hincesti (on the Romanian border) and Straseni, from where the greatest number of Moldovans emigrated to the EU and returned $\underline{6}$ (Figure 5). These populated areas are part of the Central Moldovan Development Region and share similar development characteristics. (Table 1)

Table1. Infrastructure of Development.

$\begin{array}{lccccccccccc}\text { Cities } & \text { Inhabitants } & \text { Urban } & \text { Rural } & \text { Villages } & \begin{array}{c}\text { Economic } \\ \text { agents }\end{array} & \begin{array}{c}\text { Institutions } \\ \text { Education }\end{array} & \text { Pupils } & \text { Teachers } & \text { Hospitals } & \begin{array}{c}\text { Health } \\ \text { Centres }\end{array} & \text { Doctors } \\ \text { Anenii } & & & & & & & & & & & \\ \text { Noi } & 83,100 & 8,600 & 74,500 & 44 & 18,146 & 43 & 15,129 & 852 & 1 & 16 \\ \text { Hincesti } & 122,000 & 16,800 & 105,200 & 62 & 22,100 & 53 & 16,267 & 870 & 2 & 17 \\ \text { Straseni } & 91,300 & 21,600 & 69,700 & 39 & 19,127 & 42 & 10,721 & 946 & 1 & 14 & 134\end{array}$

Source: Biroul National de Statistica al Republicii Moldova, 2011. 


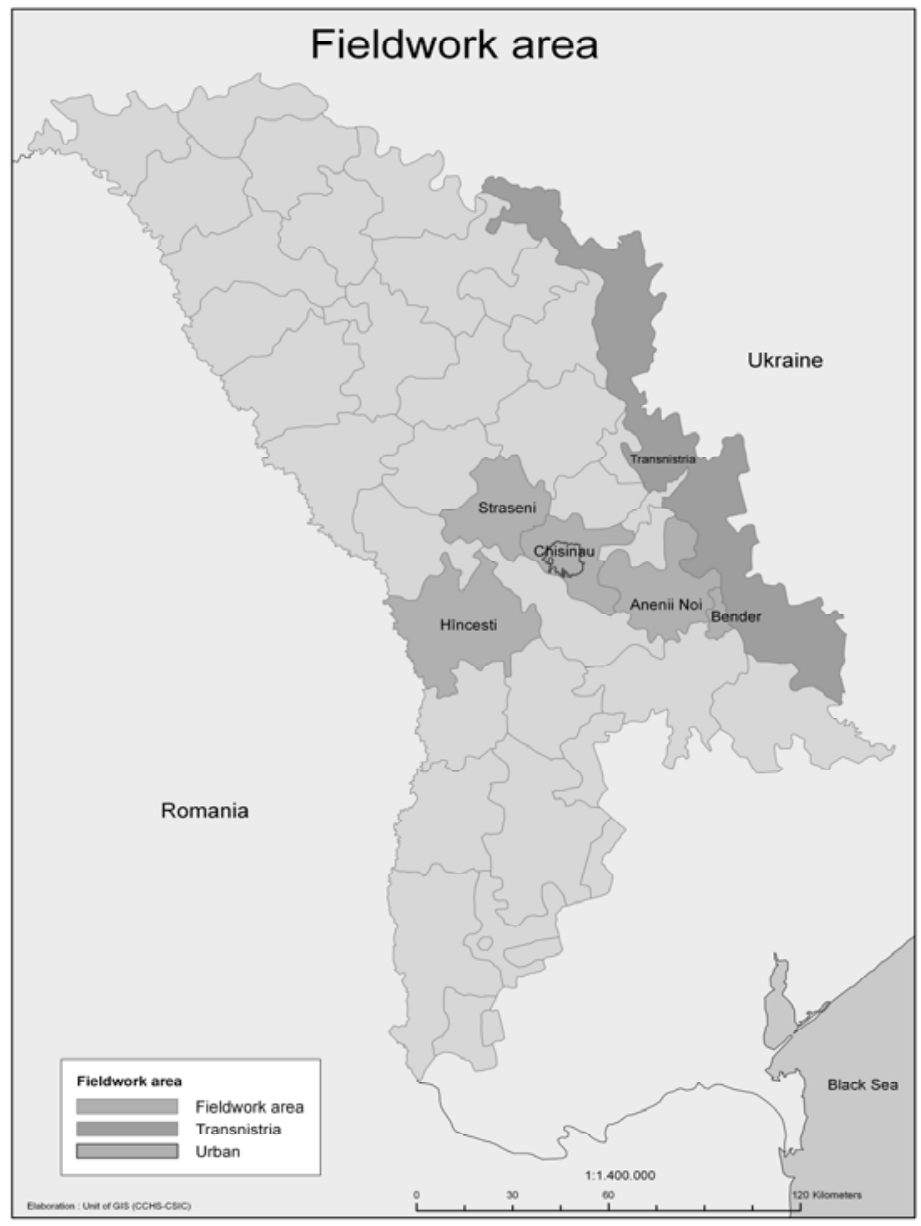

Fig. 5. Fieldwork area.

Source: Author's own elaboration, 2011.

The interviews were recorded with the permission of the interviewees, and were conducted in the Romanian language (the native language of the Moldovans) and partially in Russian and were later translated into English. I conducted interviews in both the houses of the respondents, and in businesses of returning migrants, at the offices of the mayors, and in the cafes and restaurants of selected populations. To select people, I received help from the mayors of the three municipalities (Hincesti, Straseni and Anenii Noi) and professors at the University of Chisinau. 
The questionnaire was structured in three parts. The first part includes the migrant's situation before leaving the country: demographic and social characteristics; reasons for leaving the country of origin; and education and skills and professional situation before leaving. The second part includes the migrant's experience in the main country of immigration: duration of stay; social and financial conditions in the immigration country; education and skills acquired abroad; professional and financial situation; relationships with host institutions and society; and links with the country of origin. The third and final part includes return to the country of origin and conditions for reintegration: return motivations; expected duration of the return; social and financial conditions after return; professional and financial status after return; relationships with the local institutions and the society in the country of origin after return; links with the former immigration country(ies); and post-return projects.

This approach makes it possible to understand the extent to which the experience of migration, as well as the social and institutional context at home, has an impact on patterns of reintegration.

Considering the sample as a whole, the average duration of the migration experience is 10 years; but the average duration for the migrants who were compelled to return is much shorter, especially regarding women returnees from Straseni. These contrasts are of paramount importance when evaluating the impact of the migration experience abroad on returnees' patterns of reintegration.

In 27 cases, their migrant experience aided them in creating a business in Moldova by using the social, human and financial capital they had gained in the EU. In the other 17 cases, the interviewees' experience was difficult due to the precarious legal and juridical situation in the destination country. 
In addition, I also interviewed 10 officials who specialize in the management of immigration in Moldova: the IOM coordinator in Chisinau, researchers and professors at the Academy of Science and Chisinau State University, local councillors in Hincesti and Anenii Noi, and the town Mayor of Varnita. I completed the field work in Bucharest and the headquarters of the National Authority for Romanian Citizenship (April 2011), where I interviewed the director of communications in order to better understand the process of granting Romanian citizenship to Moldovans. I also spoke with Moldovans seeking Romanian citizenship. $\underline{7}$

Using an approach taken from grounded theory $\underline{8}$ (Glaser \& Strauss, 1967), I analyzed interview transcriptions and coded them (with the Atlas Ti, 6.2 Program) according to the issues that emerged. From the beginning, I followed Barth's theory (1989), and on the presumption of disorder, later tried to organize and explain data according to the ground theory method. By using open coding, both axial and selective, four issues emerged from the interviews: cross-border experiences, return linked to development, working in Transnistria and, finally, the issue of reintegration processes and development impacts on Moldova. The emergence of these four issues helped build and homogenize the research, and they were analyzed as follows.

\section{Going deep into Moldova}

Cross-border mobility: the dual citizenship strategy

We begin the analysis by exploring the real possibilities that Moldovan citizens have of being mobile in the EU. A consequence of the implementation of the EU visa policy by the accession states has been the creation of new borders among old neighbours in Eastern Europe (Jileva, 2002). Therefore, in order to enjoy visa-free travel, Romania was obliged to abandon its legal 
regime with neighbouring Moldova, which until 1940 was part of Romania before becoming a Soviet republic, and to introduce a passport requirement for Moldovans entering Romanian territory. In 2001, the EU pressured the Romanian government to require an international passport for all Moldovans crossing the border. Therefore, the strategy used by Moldovans to cross borders was to obtain Romanian citizenship. The 1991 Law on Romanian Citizenshipg enacted two major innovations in Romanian citizenship legislation. First, it allows Romanian citizens to hold dual citizenship; second, it goes beyond the commonly accepted standard on repatriation, enabling individuals who re-acquire Romanian citizenship to retain not only their first citizenship, but also their domicile abroad. The main beneficiaries of the law are the inhabitants of the former Soviet Socialist Republic of Moldova and the provinces of Northern Bukovina and Southern Bessarabia, in the Ukraine.

According to Baldwin-Edwards (2007, p.27) between 1999 and 2002, Romania issued an unknown number of passports to Moldovan citizens: the estimates range from 200,000 to 500,000 . Since 2002, however, Romania has considerably slowed down the process of restitution for two main reasons. First, the number of applications from Moldova has increased dramatically since January 2002, when Romanian citizens were granted visa-free travel in the Schengen space, effectively clogging the bureaucratic process of restoration of nationality. Secondly, although the European Commission repeatedly stated that the policy of restitution of citizenship is an internal matter for Romania, several EU agencies voiced concerns that, upon Romania's accession in January 2007 , the country's policy on restitution of nationality could become an uncontrollable gate of access to the Schengen space of non-EU citizens, bypassing restrictive immigration policies. 
In our fieldwork, the interviewees made reference to their cross-border experience, the difficulty in departure, and the necessity of having Romanian citizenship for their mobility across Europe. Around $70 \%$ said that they had purchased the exit visa, while 30\% emigrated illegally upon receiving Romanian citizenship. Males, while they also purchased their visas, had a largely positive experience upon obtaining them, while women who had been tricked by criminal organizations had to pay excessively large sums of money to obtain a visa, or were abandoned before reaching their destination. As Maria points out,

It is a difficult experience to cross a border. We ask ourselves, 'Why do we have to go through this?' In my opinion they have no authority; the government border officials are not serious. You leave your papers for them to examine, and then you wait for a whole day. They laugh at us, and so we wait... On the Romanian border, it is very difficult at Albita. This is also to be noted when you arrive in Spain and become an irregular immigrant. (Female returning from Spain, age 53, Straseni)

Both public opinion and the various media in Moldova and Romania10 contend that the integration of 3.5 million Moldovans by the EU commenced when Moldovans 11 began to obtain Romanian citizenship. "We are a country of Moldovans with Romanian citizenship who speak Russian", noted a man who was waiting in a queue to be sworn in. Since 2011, Moldovan citizens have had the option to put their ethnicity on their birth records. In order to escape poverty, or to study or work in the West, or to reunite family members, or because of Romanian ethnicity, more than 23,000 Moldovans having ancestry in Bessarabia became citizens of Romania in 2010.

Respondents point out that, despite having no labour rights in the European countries where they worked, "we can move", noting that, "the border opening and having a Romanian passport is a 
great help". "We saved a lot of money", "we avoid corruption" and "although we are not allowed to work legally, we can more easily find work”.

"I have lived in London for two years since getting dual citizenship, and always had work", said George. (Male returning from the UK, age 49, Hincesti)

Interviewees, especially women, make reference to the difficulties they encountered in the destination country $(70 \%$ of those interviewed) because they did not have the required documents for the destination country, and because they were employed as domestic and care workers.

As Irina points out, I was not able to get legalized. They locked me up because I was illegal, and then they deported me. It was bad. For women, above all, there is great danger. Why does life have to be so bad for us? (Female returning from Greece, age 52, Straseni)

The idea of negotiating a visa-free liberalization regime with the EU12 has become one of the most important objectives of the Moldovan authorities.

Migration experience of returnees

Many scientific studies have demonstrated that migrants try to optimize their stay abroad in order to acquire the necessary skills and resources to return and reintegrate into their country of origin (Dustmann 2001). As far as the optimal migration duration is concerned, King (1986) highlights that if the duration of stay abroad is very short, say less than a year or two, the migrant will have gained too little experience to be of any use in promoting modernisation back home. 
As shown by the sample, the majority of respondents had no documents in the destination countries, therefore, could not return with any regularity to their country, being forced to endure irregular, and potential risk, return visits to their country. A significant proportion of highly skilled Moldovans undergo occupational "de-qualification" when they migrate, often employed as unskilled or low-skilled workers. The brain-drain from Moldova does not necessarily become a brain-gain for the receiving countries, but rather a brain-waste for the migrants. In addition to the common occupations of Moldovan migrants -construction in the case of men and home care or care for the elderly in the case of women- the participants in the study have worked in trade, agriculture, gardening and as waiters. In many cases, migrants have more than one job (mostly unqualified work) to obtain a larger income.

As Elvira points out:

I worked in many houses ... But of course, if you ask me for my experience.... in my opinion, it was seven years in prison, because I was away from my family. The family is broken if you live far away from each other. I endured seven years, but it was not easy. (Female returning from Portugal, age 42, Straseni)

In turn, Alexe said:

I left my job as a manager in Chisinau and worked in the UK as a building labourer... from the bottom. My diploma was not valid. Because you are nobody, you cannot say, here I am, I am an engineer ... they control you ... people lie when they say you get to a Western country and you're taken as a specialist immediately. You have to start from the bottom and prove who you are. I had no papers, and I could not say anything because they can call the police, and you can be sent back to Moldova. (Man returning from Belgium, age 50, Anenii Noi) 
It emerged that the younger men, generally, had a more tolerable experience. However, the lack of documentation gave them the feeling of being second-class citizens, employed for the worst tasks and facing difficulties in everyday life. Ovidiu points out that:

My experience ... was not so bad. I met young people. I think as a country, Italy is a developed country, and also in the area of construction. I learned the language; it was a good experience. However, you are nobody, because you are undocumented ... Now, if I think about it, I do not regret having gone, but I'm not very happy thinking of those years. (Man returning from Italy, age 30, Hincesti)

On the contrary, middle-aged women confess the suffering and difficulties that they experienced. Lavinia notes that:

It was painful being away; the experience can destroy you if you're not strong. You think of your children, your family. Because you are a foreigner, it is difficult to succeed. They exploit you and pay you very little. (Female returning from Italy, age 52, Straseni)

In fact, $80 \%$ of respondents confessed they earned little during the years of emigration to other countries, and they made serious efforts to save money.

As Elvira told us:

I earned little money during seven years. I saved it and never left home because I had to send money to my children. Anyway it was hard to leave the home because I did not have an identity card in Portugal. (Female returning from Portugal, age 42, Straseni).

Despite two decades of migration experience, illegal migration from Moldova still remains a problem. Therefore, the irregular status of migrants increases the risk of ill treatment by local 
authorities, and often pushes migrants into illegal employment and sub-standard working conditions, leading to lower earnings and remittances sent by migrants.

Our interviewees also suggest that the global economic crisis has affected their employment status and their earnings abroad. Migrants are facing reduced work hours, reduced incomes, job loss, difficulties finding a job and, in some cases, expenses for accommodation and food that were formerly covered by the employer have been deducted from monthly compensation. This in turn, has affected the remittance and savings capacity of migrants. According to a study by IOM (2012) $31 \%$ of remittance-sending migrants sent fewer remittances to their families in Moldova in 2012 than in 2011; while 47\% of receiving families reported receiving fewer remittances than 2011. These data confirm the official estimates depicting a drop in the value of transfers in 2011. According to the National Bureau of Statistics, as a result of these decreases in remittances, as well as other factors during 2011, the overall GDP in Moldova fell by $6.5 \%$.

In our fieldwork, Luminita said:

The salary was decreased by $20-30 \%$ and we are sending home less. (Female returning from Italy, age 50, Straseni).

In turn, Oleg points out:

The crisis is being felt. There was less work and certainly we were saving less. At the time the crisis began, my position was lowered and I lost my job. However, this was the reason that made me come back home and start my own business. (Man returning from Spain, age 51, Anenii Noi)

However, according to the migrants interviewed, the main benefit of migration is economic, although migration experiences have also changed migrants' mentalities, their vision and 
concepts of life, and ways of planning life and have taught them to be more flexible, adapt more easily and to find power for survival. Migration allowed them to become acquainted with new technologies, to learn various strategies of planning and organizing businesses; to undertake some business ideas and to put them into practice upon return to the home country.

\section{Finding strategies: return for development}

An important element not analysed widely in the literature is return migration for development, especially in countries which have a significant level of temporary migration, not only in terms of the migrants themselves, but in the sending country's labour market as well. This paper helps to fill the gap by analysing the strategies choice of return migrants in Moldova. This is an important aspect to determine the overall impact on the labour market and consequently on the growth and development prospects of the country. The paper, thus adds to the existing literature, which mostly used the data from more traditional (long-term) migration countries, on the activity choice of return migrants. As Levitt \& Lamba-Nieves (2011) rightly point out, return and social remittances behaviour may influence the development of a country.

The return home is conditioned by a number of factors. Respondents noted that their decision to return depended primarily on the economic crisis that affect their employment status in destination countries, but also their family situation and the prospects of working in Moldova. When making the decision, they relied on the information about the possibilities of development of their country. They stressed that the best option was to set up their own business, using the experience gained during the migration process. Interviewees point out that they often encounter 
difficulties when re-integrating into Moldovan society, lacking the infrastructure, opportunities and support available to them previously in the countries of migration.

Despite these conditions, it was clear that those who returned who possess some capital for investment and who have an entrepreneurial spirit and are willing to undertake some risks choose to invest in Moldova. Of the 44 people interviewed, 27 had set up their own business. They are, precisely, the dual citizens; those who can practice mobility. As Ioana noted, My husband and I have an optical business, which is the first in the city. We have customers... However, I also have a translation company, because I prefer work in the translation of Russian, English, Romanian and Portuguese. I need to keep these languages alive because I don't know when we will need them. As we have Romanian citizenship, we can practice mobility. (Female returning from Portugal, age 45, Hincesti)

Investments were made for the most part with income that had been accumulated during the time spent outside of Moldova or, in just a few (3) cases, from programmes coordinated by the IOM: the Agency of Migration and Development 13 and PARE 1+1.14 Regarding this, Cornel said:

I applied for and obtained significant financial aid to open my own business. It is an agricultural cooperative, where we have fruit trees, bees and vines. The beginning was difficult, but now the results are good and I see that with the aid, things are getting better, because I can also employ people. (Male returning from Spain, age 47, Hincesti)

According to the interviewees, businesses are started with very few resources that do not surpass more than a few hundred euros. The largest sum invested amounted to $€ 50,000$. There were also 4 cases of couples in which one partner (generally, a woman) worked outside of the country while the male partner managed the business. As Dorin explained, 
My wife works in Italy and sends money every month, so I can keep the market and make things work. It's like a chain. (Male returning from Italy, age 48, Straseni)

This study revealed situations in which the financial, human and social capital acquired by Moldovans abroad is instead channelled towards, for example, Romanian border communities. Even if few such cases exist at the moment, there is a potential for these numbers to increase in the future, especially since obtaining Romanian citizenship by Moldovans has become easier. Sorin recognized:

I tried to start a business here in Hincesti but, in the end, we took it to Galati across the border. There are lots of hairdressers, pharmacies and food stores that are in Romania because there is less bureaucracy there. (Male returning from Italy, age 51, Hincesti)

Interviewees point out the importance of the human, social, and even psychological and cultural capital they acquired during the process of migration. Most of them agree that the opportunity to migrate and live abroad transforms migrants' general attitude and vision in several ways. This has an impact on the way of doing things and how they perceive themselves and others. It has a positive impact on the host country as well: "We were treated well, people are polite, smiling and very friendly"; "One learns many things there, although higher value is still on the money".

Therefore, as Marin points out,

If it were possible to accomplish things in our country, about $90 \%$ of the people would return. We like Europe and want to live as we do in Europe, but we have to learn how to behave as they do in Europe. It is necessary for businesses to succeed in a country that taxes are paid, and that people are well. But here in our country, it is the bars, cafés and restaurants that work. 
Corruption is overwhelming. In fact, it is we the returning emigrants who have to change things. We need to unite and put change into effect. (Male returning from Ireland, age 48, Straseni)

The situation for the remaining 17 interviews continued to be difficult because they had exhausted the resources saved during the period of their emigration and were unemployed at the time of the interview. We can say that these were cases of marginal return in vulnerable situations. As a result, many migrants resort to repeat migration. But to emigrate again, under the current conditions, is difficult. 15

Maria remembered with sadness:

Once I returned without papers... And I left again, paid €3,000, and the route was very dangerous; my life was in the balance. There are thousands of people in Moldova who have been unable to return, who suffer. It is because Moldova is throwing us out that we have to leave (Female returning from Spain, age 53, Straseni)

"It is important for there to be cross-border mobility towards the EU", said the IOM coordinator of Moldova, because in comparison to emigration to Canada or the United States, it is a process that produces benefits for Moldova in terms of remittances, economic growth, return, the human factor and the change in the mentality of the people who emigrate and their families.

\section{Working in Transnistria}

Since some interviews were conducted in the town of Varnita, on the border with Bender (Transnistria), an important theme that emerges in this fieldwork was the issue of Transnistria. Since 1992, a low-intensity economic conflict has grown between Moldova and Transnistria, 
which has run in parallel with conflict settlement resolutions negotiated on the political level. Between the two, there is a natural border, the Dnestr River. Since the end of the war, in 1992, on the one hand Moldova has been working for the economic reintegration of Transnistria, while, on the other hand, Transnistria has been fighting to become an independent and sovereign state; thus, a real purported border was created between the two banks of the river, with crossingpoints, border guards and custom posts (Roper, 2005). As Popescu notes, (2005, p.18) Transnistria has blocked the development of five sectors of common spaces -economic, legal, defence, trade and cultural- with Moldova. Tiraspol introduced in 2002 an import tax of 20\% to all Moldovan goods and in 2003 increased it to 100\% for the same goods. The consequences of this entire political and economic problem led to a failure of intra-Moldovan commerce and the economy. Bender, on the border with Varnita (see Figure 5), is a prosperous city in Transnistria, a factor which may shape the views of the people interviewed. The people of Varnita move daily to Bender, where they work. They returned from abroad opened businesses in Transnistria and brought ideas, knowledge and information learned through mobility. They live daily with the citizens of Transnistria, who are clients of their businesses (food stores, repair workshops, and printing works). Ion said that:

We get on well... Transnistrian come to buy from my market and ask me about my life abroad ... what language I learned, and if it is difficult to find work in Spain. (Male returning from Spain, age 48 , Straseni)

In turn, Alexei said:

I have a friend who also wants to migrate to Italy... He has experience of migration to Moscow, and sometimes we talk about what one can earn and in which sectors if you work in Russia or in Italy... (Male returning from Italy, age 35, Varnita) 
Their experiences abroad challenged and expanded how they did things and why they did them, and their attitudes to share experiences and open businesses in Transnistria show that they foment society synergies and collaboration with the people of Transnistria. Participants in this work described life in Transnistria as good: gas, electricity and accommodation were cheap. "In the evenings, the street lights blazed in Bender, while it was dimly lit in Varnita".

In turn, the Major of Varnita notes that: We do not perceive Dniester as a barrier... I think there are possibilities if there are good relations among people... We tried to cooperate with Bender, since we share in common our electricity, natural gas, and telephone networks. There are 6,150 of us. Many young people have left town, but there are also returning emigrants who build homes with the money they earned in the EU. These people help with their new ideas. They know languages, and seem to be more open than us...they are more European. (Mayor of Varnita)

According to interviewees, there are more opportunities for opening up businesses in Transnistria, prospering and even retirement. In Moldova, the retirement age is 62, while in Transnistria it is set at $55 . \underline{16}$

As Ovidiu explained,

I opened a food store in Bender when I returned from Spain, even though I live in Varnita. It means a few kilometres every day. I already knew that everything was easier there because gasoline costs less. The business is going well; we...the people...understand each other. We have ties. In the end, we are all the same, and we all speak Russian. (Male returning from Ireland, age 45, Varnita)

Thus, the return of Moldovans and the opening of businesses across the Dniester facilitate the coexistence between people, and can support the easing of tensions. Their work experience in EU 
countries, and the exposure to ideas, values and practices that they bring back with them, influence the types of social remittances returned -clearly both social and cultural. As Secrieru (2011) notes, domestic development provides a start for building a favourable setting for a sustainable solution in the long run.

Return, the re-integration process and development impacts in Moldova

Despite the increasing permanent nature of Moldovan migration, the effects of the economic crisis have meant an increase in return. The crisis led to deterioration in poverty and human development, notably in rural areas, with approximately one fifth of migrants returning in 2011. According to IOM, in $1^{\text {st }}$ quarter of $2011,18 \%$ more Moldovan migrants returned compared to the respective period of 2010 . Those who return enter an already contracted labour market (54\% increase in unemployment in $1^{\text {st }}$ quarter of 2011 compared with 2010; one third of the unemployed are under 29). Many returnees find it difficult to integrate into the domestic labour market, due to the stiff competition (more than 10 applicants competing for each vacancy).

According to our sample, for some migrants, the skills and experience acquired abroad help them find better employment back home. However, according to OIM, returnees rarely find employment in the same sector in which they had worked abroad (except those who worked in construction, a sector which has seen a boom in Moldova).

For most returnees, "homecoming" tends to generate high expectations. In the case of Moldova, problems were compounded by the resettlement strategy adopted; large numbers of people were returned to their rural homes thereby generating pressure on the fragile economic and 
environmental resource base. Given their location in scattered rural settlements returnees were effectively isolated from towns and from potential job markets. As Maria explains:

I have not been able to find a job since my return. My husband earns just over 3,000 Moldovan lei, and natural gas costs us 2,700 lei per month. Imagine how we live. We survive because we have a vegetable garden. We only buy food in winter. But we always have to save. (Female returning from Spain, age 53, Straseni)

Another important problem of reintegration is the high level of corruption that is not only encountered in the areas of information and bureaucracy, but also "accompanies" the entrepreneur throughout every stage of launching and operating the business. As Luminita noted,

To register a business in our country means to pay money in order to open doors. (Female returning from Italy, age 50, Straseni)

In the same vein, Oleg explained that:

The Labour Division has the responsibility to provide us with some information free of charge, for instance, information regarding labour safety. But they asked for money. I wanted to notify the anti-corruption service, but I was warned that these institutions are closely connected and assist each other. (Man returning from Spain, age 51, Anenii Noi)

While Vasile concluded:

I know people who brought money home and wanted to start a business, but due to red tape and corruption gave up the idea and went back abroad. (Man returning from Greece, age 53, Hincesti) 
Therefore, the failure to integrate into the Moldovan labour market upon returning home, as well as poor infrastructures, especially in rural areas, thus became motivating factors (push factors) to continue migration. As León-Ledesma \& Piracha (2004) point out, many migrants prefer to leave Moldova again in order to seek livelihoods abroad.

Thus, it is important to note that the tendency to re-migrate for the purpose of obtaining work is common among Moldovan migrants. The most frequently mentioned reasons for re-migration were insufficient money for setting up, operating or expanding a business. In some cases, remigration is instigated by the failure of a business, and therefore serves as a solution for securing a satisfactory livelihood. Other reasons for re-migration include the availability of a robust and safe social security system in the destination country, lower levels of corruption and bureaucracy compared to the Republic of Moldova, and better quality and provision of services.

Laura points out that:

I am not happy. I think that after getting a Romanian passport, I will emigrate again. Over the following 10 years everyone will migrate and work abroad and then come back home. If we look realistically at things, nothing is happening in this country. We realise that if Moldova still exists as a country, it is only due to the fact that we slave abroad and bring back money." (Female returning from Spain, age 43, Hincesti)

Young returnees recognize that it is difficult, but remain hopeful. As Bogdan said:

I want to stay in my country. I speak Russian, English, Spanish and Romanian. Maybe I will be lucky. I lack information and support; where I am nobody tells you anything. (Man returning from Spain, age 29, Straseni) 
Thus, we can note that Moldova still demonstrates a deficiency in the area of a comprehensive policy framework for return migration, which requires an explicit national policy, an organized institutional structure, and an effective coordination mechanism of migration policies.

Therefore, as Arowolo (2000) rightly notes, programmes for the economic reintegration of returnees must be based on a careful analysis of their background characteristics: age, sex, education/skills acquired, reasons for leaving, type of work done while away, family characteristics, amount of money repatriated, and access to property at home. These determine the individual needs for economic integration or reintegration. In addition, the absorptive capacity of the local economy must be set against the potential demand by returnees for employment. If information is lacking, or of poor quality, the returnees or the local economic environment planning for smooth reintegration could see this rendered difficult.

\section{Conclusions}

In this article we examined the perceptions of returned Moldovans engaged in cross-border mobility in the countries of the EU. In answering the research questions posed at the beginning of the article, the following conclusions can be made.

First, the geopolitical position of the region, on the border between Russia and EU, influences the emigrants that return to their country. Migrants point out the isolation that they suffer because of

a border that separates them from the rest of Europe. As such, the border both unites and separates them; it integrates and fragments them, at the same time. The difficulty of both juridical and labour integration within the countries of the EU impels emigrants to return but with the conviction that their country must become integrated into the system of western values. 
Legal intervention would support regular migration and, as a result, would support development objectives by increasing migrants' incomes, remittances and savings values and encouraging the use of formal transfer channels (Arowolo, 2000). Moreover, legal status is a prerequisite for migrants to initiate and to take part in activities designed to foster community cohesion and links to the homeland. It also facilitates more frequent returns home. As Hugo (2012, p.44) rightly points out, there is a need to reconceptualise return migration to include a range of strategies beyond a one-off permanent return movement to the homeland. From a policy perspective, a 'development friendly' approach at the destination would encourage dual citizenship/residence and facilitate movement to and from origin countries.

Secondly, for Moldovans, migration is a life strategy. While remittances are for now an important advantage, it has been demonstrated that emigrants' return and their opening of businesses may help to strengthen the ties between mobility and development. However, the decision to start up a business is frequently hindered by a failure to re-integrate into the Moldovan labour market. In spite of the difficulties and challenges facing small enterprises, migrants remain generally optimistic, and trust that decision makers will change their attitudes towards small-scale producers. While individuals communicate ideas and practices to each other in their roles as friends, family members or neighbours, they also communicate in their capacity as organizational actors, which have implications for organizational management and capacity-building (LeonLedesma \& Piracha, 2004). We have seen through the return-development debate why it is important to include social remittances into the equation.

Thirdly, according to the results of this study, we have also seen how the return of Moldovans and the opening of businesses across the Dniester facilitate the coexistence between people and the easing of tensions. 
Finally, as Olesen (2002) points out, providing returning migrants with socio-professional reintegration assistance and employment opportunities can prevent re-migration and act as a pull factor for those still abroad. Active participation of the target group in the selection of the reintegration option that best suits their needs and abilities will enhance their successful reintegration. That is why actions are needed to enhance the homeland development potential of migrants' resources and offset the detrimental social consequences of migration. Reintegration assistance may consist of provision of the following options: support for small business development or business start-up plans, assistance in finding a job in state-owned or private institutions/enterprises, and, if needed, support offered to employers, vocational training (for example, mechanics, machinists, hair dressers, sanitary technicians, electricians) covering the costs of tuition fees, and the procurement of working tools upon successful completion of training covering the costs of the equipment, among others.

Furthermore, the results of this study suggest that -in cooperation between Moldova and migrant receiving countries- migration policies should focus mainly on fluid cross-border mobility, on the optimal length of legal residence granted and on the appropriate measures to encourage return for development and reintegration to the home country.

\section{Notes}

[1] According to IOM specialists L. Vasilova and T. Jordan, interviews collected in April 2011 showed that $90 \%$ of remittances were used for consumables, while $10 \%$ were destined to development.

[2] Of these, 237,690 live in countries of the EU.

[3] The GDP per capita was 2,500 USD in 2008 (7,800 USD in Ukraine; 12,500 USD in Romania; and 33,800 USD in the European Union. World Bank: Report No. 55195-Moldova; April 4, 2011.

[4] http://www.border.gov.md, accessed August 17, 2012.

[5] During the months of July 2010 to April 2011, I undertook field work within the framework of a project on mobility and return (CSO2010.14870). 
[6] Even though previously I contacted the local counsellors later, I used the snowball technique and interviewed returning Moldovans in public places (official offices, and cafés) or in their homes.

[7] Aside from the interview with the IOM coordinator, the rest of the interviews were conducted entirely in Romanian and then translated into English.

[8] Grounded theory is a method that begins by collecting data and by means of the data there are detected codes by which information is extracted. The codes are grouped according to similar concepts from which categories that offer a basis for a reverse-engineering theory or hypothesis are formed.

[9] Romanian citizenship Law 21/1991 http://legislatie.resurse-pentrudemocratie.org/21_1991.php,; http://www.romanianpassport.co.il/english/romanian-citizenship-law/ accessed September 22, 2012.

[10] http://romanialibera.ro/actualitate/eveniment/de-10-ori-mai multe-cereri-pentru-cetatenia-romana-196678.html accessed August 4, 2012.

[11] "Evadarea din Chisinau spre Europa" Romania libera 9 Mai, 2011. http://www.romanialibera.ro/exclusivrl/reportaj/evadarea-din-chisinau-spre-europa-cum-devin-moldovenii-romani-cu-acte-in-regula-224748.html, accessed August 7, 2012.

[12] EU commissioner welcomes Moldova's progress on visa free regime agenda" - Söderköping Process. http://soderkoping.org.ua/page28732.html, accessed August 7, 2012.

[13] (IOM), Mission to Moldova, is implementing a three-year project, "Supporting the implementation of the migration and development component of the EU-Moldova Mobility Partnership," in order to minimize the negative effects of migration and to harness the benefits for development purposes.

[14] On November 22, 2010, the pilot Program on Attracting Remittances into the Economy PARE 1+1 was launched. The programme aims to stimulate the transfer of remittances through official channels, transfer knowledge and know-how, facilitate the access of migrants to funds, and create new places of work in Moldova.

[15] Approximately $80 \%$ of the population had never travelled to an EU country (except for Romania). Only $11 \%$ indicated that they would travel to an EU country for employment in the following year if allowed to circulate without a visa. http://ipp.md/libview.php?1=ro\&idc=150\&id=562, accessed July 2, 2012.

[16]http://www.europalibera.org/content/article/1816928.html, accessed June 15, 2011.

\section{References}

Agnew, J. (2008). Borders on the mind: re-framing border thinking. Ethics and Global Politics, $1(4), 175-191$.

Ammassari S., \& Black R. (2001). Harnessing the Potential of Migration and Return to Promote Development: Applying Concepts to West Africa. IOM Migration Research Series 5. IOM,

\section{Geneva.}


Andreas, P. (2003). Redrawing the line: borders and security in the twenty-first century. International Security, 28 (2),78-111.

Arowolo, O. (2000). Return Migration and the Problem of Reintegration. International Migration, 38 (5), 59-82.

Athukorala, P. (1986). Sri Lanka's Experience with International Contract Migration and Reintegration of Return Migrants, ILO, Geneva.

Baldwin-Edwards, M. (2007). Navigating between Scylla and Charybdis: Migration Policies for a Romania within the European Union. Southeast European and Black Sea Studies, 7 (1), 345-378.

Barth, F. (1989). The Analysis of Culture in Complex Societies. Ethnos, 54 (3-4), 120-142.

Cassarino, J-P. (2004). Theorising Return Migration: The Conceptual approach to return migrants revisited. International Journal on Multicultural Societies, 6 (2), 253-279.

Chapman, M., \& Mansell Prothero, R. (1983). Themes on circulation in the Third World. International Migration Review, 17 (4), 597-632.

Cuc, M., Erik, L., \& Ruggieri, E. (2005). Migration and remittances in Moldova, technical report. Washington D.C: International Monetary Fund.

Culic, I. (2008). Eluding exit and entry controls: Romanian and Moldovan immigrants in the European Union. East European Politics and Societies, 22 (1), 145-170.

De Haan, A. (1999). Livelihood and poverty: the role of migration. A critical review of the migration literature. Development Studies 36 (2), 3-47. 
Dustmann, Ch. (2001). "Return Migration, Wage Differentials, and the Optimal Migration Duration", Discussion Paper n. 264, Institute for the Study of Labour, Bonn.

Ebeke, C. (2012). Do Remittances Lead to a Public Moral Hazard in Developing Countries? An Empirical Investigation. Journal of Development Studies, 48 (8), 1009-1025.

Faist, T. (2000). The Volume and Dynamics of International Migration and Transnational Social Spaces. Oxford: Clarendon.

Favell, A. (2008). The new Face of East-West Migration in Europe. Journal of Ethnic and Migration Studies, 34, 701-716.

Galor, O., \& Stark, O. (1990). Migrants' Savings, the Probability of Return Migration and Migrants' Performance. International Economic Review 31, 463-467.

Gielis, R. (2009). Borders make the difference: migrant transnationalism as a border experience. Tijdschrift voor economische en sociale geografie, 10 (5), 598-609.

Glaser, B., \& Strauss, A. (1967). The discovery of grounded theory: strategies for qualitative research. New York: Aldine.

Glick Schiller, N., Basch, L., \& Szanton Blanc, C. (1992). Transnationalism: A new analytic framework for understanding migration, in: N.Glick Schiller, L.Basch, \& C.Szanton Blanc (Eds.), Towards a transnational perspective on migration: Race, class, ethnicity and nationalism reconsidered, New York Academy of Sciences: New York, 1-24.

Görlich, D., \& Trebesch, C. (2008). Mass migration and seasonality. Evidence on Moldova’s labour exodus. Review of World Economics, 144 (1), 107-133. 
Hannam, K., Sheller, M., \& Urry, J. (2006). Editorial: Mobilities, Immobilities and Moorings, Mobilities 1, 1-22.

Hugo, G (2012). Migration and development in low-income countries: a role for destination country policy?, Migration and Development, 1(1), 24-49.

IOM (2012) Moldova: Enhancing the Development Potential of Return Migration, Organisation Internationale pour les Migrations, Geneva, $230 \mathrm{pp}$.

IOM (2004), Return Migration: Policies and Practice in Europe, Organisation Internationale pour les Migrations, Geneva, 402 pp.

Jileva, E. (2002). Visa and free movement of labour: The uneven imposition of the EU acquis on the accession states. Journal of Ethnic and Migration Studies, 28 (4), 683-700.

Khagram, S., \& Levitt, P. (2007). The Transnational Studies Reader. New York and London: Routledge).

King, R., \& Christou, A. (2011). Of Counter-Diaspora and Reverse Transnationalism: Return Mobilities to and from the Ancestral Homeland, Mobilities 6 (4), 451-46.

King, R. (2000). Generalisations from the history of return migration. In Return Migration: Journey of Hope or Despair? Ghosh B (ed.). IOM: Geneva, 7-55.

King, Ch. (2003). Marking time in the middle ground: contested identities and Moldovan foreign policy. Journal of Communist Studies and Transition Politics, 19 (3), 60-82.

King, R. (1986) (ed.), Return Migration and Regional Economic Problems, Croom Helm, London.

Leon-Ledesma, M., \& Piracha M. (2004). "Return Migration and the Role of Remittances in Eastern Europe". International Migration, 42 (4), 65-83. 
Levitt, P., \& Lamba-Nieves, D. (2011). Social Remittances Revisited. Journal of Ethnic and Migration Studies, 37 (1),1-22.

Levitt, P. (2001). The Transnational Villagers. Berkeley: University of California Press.

Marcu, S. (2011). Opening the Mind, Challenging the Space: Cross-border Cooperation between Romania and Moldova, International Planning Studies 16 (2), 109-130.

Marcu, S. (2009). The Geopolitics of the Eastern Border of the European Union: The Case of Romania-Moldova- Ukraine. Geopolitics, 14 (3), 409-432.

Merkle, L. \& Zimmermann, K. (1992). Savings, remittances, and return migration. Economics Letters, 38 (1), 77-81.

Newland, K., \& Patrick, E. (2004). Beyond remittances: The role of diaspora in poverty reduction in their countries of origin. Washington, DC: Migration Policy Institute.

Newman, D. (2006). The lines that continue to separate us: borders in our 'borderless' world. Progress in Human Geography, 30 (2), 143-161.

Olesen, H. (2002) Migration, Return, and Development: An Institutional Perspective. International Migration, 40 (5), 125-150.

Papademetriou D., \& Martin P. (eds). 1991. The Unsettled Relationship: Labor Migration and Economic Development. Greenwood Press: Westport, CT.

Pinger, P. (2009). Come back or Stay? Spend here or there? Return and remittances: The case of Moldova. International Migration, 48 (5), 142-173.

Popescu, N. (2005). The EU in Moldova - Settling conflicts in the neighbourhood, Occasional Paper no 60, European Union's Institute for Security Studies (available at: http://www.iss.europa.eu/uploads/media/occ60.pdf Accessed 28 October 2012. 
Portes, A., Guarnizo, L., \& Landolt, P. (1999). The Study of Transnationalism: Pitfalls and Promise of an Emergent Research Field. Ethnic and Racial Studies, 22(2), 217-237.

Preston, R. (1993) The Integration of Returned Exiles, former Combatants and Other WarAffected Namibians; Namibia Institute for Social and Economic Research, Windhoek, Namibia.

Roper, S. (2005). The politicization of education: Identity formation in Moldova and Transnistria. Communist and Post-Communist Studies, 38, 501-514.

Ruggiero, E. (2005). Migration and remittances. Problems of Economic Transition, 48 (3), 54-83. Rumford, C. (2007). Does Europe Have Cosmopolitan Borders? Globalizations, 4 (3), 327-339.

Rusnac, G., Moşneaga, V., Moraru, V., \& Turcan, V. (2011). Faţetele unui proces: migraţia forței de muncă din Republica Moldova în Italia. Chişinău: Prim.

Secrieru, S. (2011). The Transnistrian conflict - new opportunities and old obstacles for trust building (2009-2010). Journal of Southeast European and Black Sea Studies, 11 (3), 241-263. Vertovec, S. (1999). Conceiving and Researching Transnationalism. Ethnic and Racial Studies, $22(2), 447-490$.

World Bank. (2003). Global Development Finance. World Bank: Washington DC. 